\section{International Symposium and Field Workshop on Ediacaran and Cryogenian Stratigraphy}

\author{
11-22 June 2014, Hubei, Hunan, Guizhou, and Guangxi \\ Provinces, South China
}

The Neoproterozoic Era (1000-542 million years ago) is emerging as one of the focuses in Earth system history studies. It is a geological interval of dramatic climatic change and important evolutionary innovations. The early Neoproterozoic is characterized by the final assembly and subsequent disassembly of the Rodinia supercontinent (Hoffman, 1991), associated with extensive continental rifting events. Global glaciations of unusual magnitude occurred in the Cryogenian Period (Kirschvink, 1992; Hoffman et al., 1998; Hoffman and Schrag, 2002; Jiang et al., 2003). The subsequent Ediacaran Period (Knoll et al., 2004, 2006) witnessed the radiation of various eukaryotes, including animals (Gehling, 1991; Xiao et al., 1998; Bottjer and Clapham, 2006; Jensen et al., 2006; Liu et al., 2010; Erwin et al., 2011; Chen et al., 2013; Carbone and Narbonne, 2014), macroalgae (Xiao et al., 2002; Yuan et al., 2011), a unique assembly of acanthomorphic acritarchs (Zhang et al., 1998; Grey, 2005; Liu et al., 2014; Xiao et al., 2014), and classical Ediacara organisms (Narbonne, 2005; Fedonkin et al., 2007; Xiao and Laflamme, 2009; Liu et al., 2012; Gehling and Droser, 2013; Chen et al., 2014; Grazhdankin, 2014; Narbonne et al., 2014). There is increasing evidence suggesting that these evolutionary events may have been coupled with the progressive oxygenation and ventilation of the global oceans (Lenton et al., 2014; Lyons et al., 2014).

These exciting developments demand more rigorous stratigraphic subdivision and correlation of Neoproterozoic strata, particularly the Ediacaran and Cryogenian systems. To cultivate healthy discussion among Neoproterozoic workers, coordinated international efforts have been made to provide a platform for information exchange. These include the Subcommission on Ediacaran Stratigraphy, Subcommission on Cryogenian Stratigraphy, IGCP Project 512 (Neoproterozoic Ice Ages), IGCP 587 "Of Identity, Facies and Time: the Ediacaran (Vendian) Puzzle", among many others. In response to a 2012 survey carried out by the Subcommission on Neoproterozoic Subcommission, an international field workshop was organized to examine Ediacaran and Cryogenian stratigraphy in South China.

The choice of South China as a focus of this field trip is also motivated by the many contributions of Chinese scientists to our understanding of Neoproterozoic stratigraphy and paleontology, as well as the opportunity to observe Neoproterozoic successions at many localities across the Yangtze Craton, from shallow-water inner shelf facies to deepwater basinal facies (Fig. 1). Two and possibly

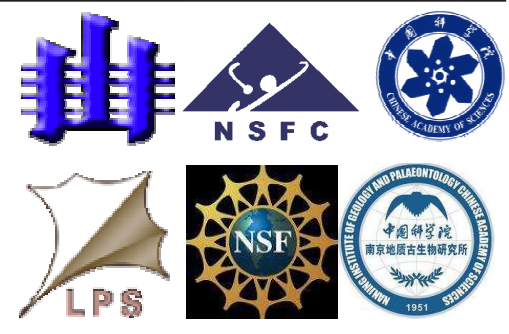

three discrete glaciation events are recorded in Cryogenian successions in South China (Zhou et al., 2004; Zhang et al., 2011). The cap carbonate atop the terminal Cryogenian glacial deposit in South China is one of the best studied cap carbonates (Jiang et al., 2003; Jiang et al., 2006; Zhou et al., 2010; Bristow et al., 2011). Ediacaran successions in South China contain exceptionally preserved microand macrofossils, as well as abundant trace fossils, that have the potential to illuminate the early evolutionary history of animals and other multicellular eukaryotes (Xiao et al., 1998; Xiao et al., 2002; Yuan et al., 2011; Chen et al., 2013; Chen et al., 2014; Liu et al., 2014; Meyer et al., 2014; Xiao et al., 2014). In addition, Ediacaran successions in South China are characterized by mixed carbonates, phosphorites, and shales, providing opportunities for integrated chemostratigraphic and biostratigraphic

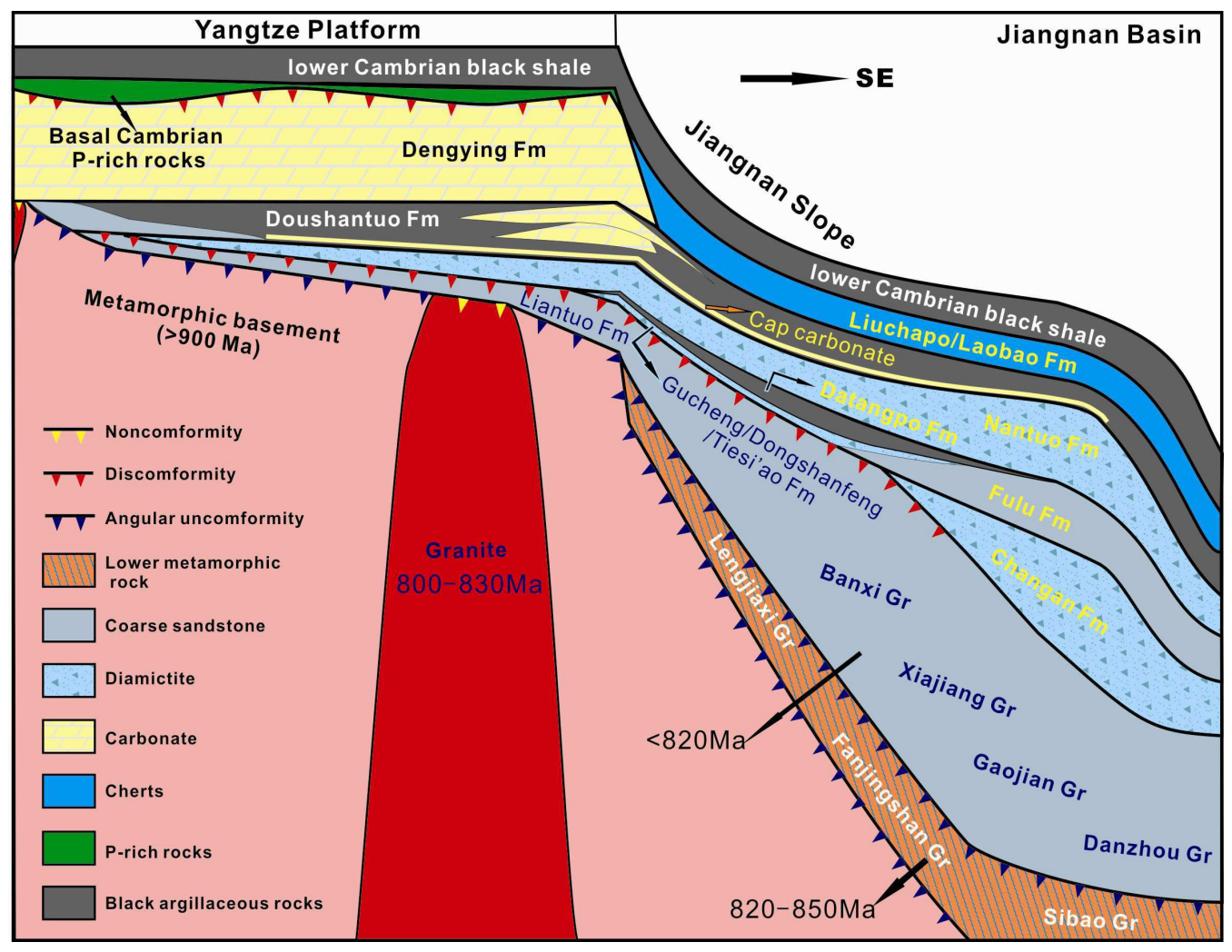

Figure 1. A conceptual model of the Cryogenian-Ediacaran stratigraphic relationship across the Yangtze platform, from shallow water shelf facies (left) to deep water slope and basinal facies (right). Diagram prepared by Maoyan Zhu. 
investigation (Kaufman and Knoll, 1995; Zhou and Xiao, 2007; Zhou et al., 2007; Zhu et al., 2007; McFadden et al., 2008; McFadden et al., 2009; Yin et al., 2009; Xiao et al., 2012; Liu et al., 2013; Zhu et al., 2013). Finally, available radiometric dates from South China provide broad geochronological constraints and calibration of Neoproterozoic stratigraphy (Zhou et al., 2004; Condon et al., 2005; Zhang et al., 2008a; Zhang et al., 2008b; Gao et al., 2013). The new data will undoubtedly play a central role in the stratigraphic correlation of Ediacaran and Cryogenian strata.

The workshop starts with a 4-day field excursion (11-15 June 2014) to examine the Ediacaran and Cryogenian successions deposited in inner shelf facies in the Yangtze Gorges area of Hubei Province, focusing on the 750-720 Ma Liantuo Formation sandstone, the terminal Cryogenian Nantuo Formation diamictite (654-635 Ma), Ediacaran Doushantuo and Dengying formations (635-541 Ma), and the Ediacaran-Cambrian boundary in the Yanjiahe Formation. Participants debated on the depositional environment of the Liantuo Formation, whether the Liantuo Formation is part of the Tonian or Cryogenian System, the correlation of the Nantuo Formation and other Cryogenian diamictites in South China and beyond, the origin of extremely negative carbonate carbon isotopic values in the Doushantuo cap carbonate, sequence stratigraphy of the Doushantuo Formation, significance of carbon isotope chemostratigraphy and acritarch biostratigraphy in the subdivision and correlation of the Ediacaran System, as well as how to integrate biostratigraphic data (e.g., small shelly fossils, acritarchs, and trace fossils) and chemostratigraphic data (e.g., carbon and strontium isotopes) to correlate the Ediacaran-Cambrian boundary between carbonate and siliciclastic facies. The field excursion also highlighted recent progress on Ediacaran biostratigraphy based on acanthomorphic acritarchs from the Doushantuo Formation (Liu et al., 2014) and new discovery of classical Ediacara fossils including Pteridinium, Rangea, Charniodiscus, and Hiemalora from the Dengying Formation (Chen et al., 2014).

The Yangtze Gorges field excursion was followed by a three-day symposium in Wuhan (16-18 June 2014), held together with the $3^{\text {rd }}$ International Conference of Geobiology. The symposium included 31 oral presentations and 20 poster presentations. In addition, the $3^{\text {rd }}$ International Conference of Geobiology had a symposium with 10 oral presentations focusing on Precambrian geobiology. On June 18 , participants had an opportunity to examine microfossils (e.g., acanthomorphic acritarchs, embryo-like microfossils, and tubular microfossils) from the Doushantuo Formation, macrofossils from the Lantian Formation, and Ediacara fossils from the Dengying Formation. Several participants also shared published and unpublished material from the Ediacaran Ura Formation in Siberia and the Biskopås Formation in southern Norway. During the symposium, eleven voting members and six corresponding members of the Ediacaran Subcommission held a meeting to discuss strategies to divide the Ediacaran System, and made several recommendations that will be communicated to the Subcommission at a later time.

After the Wuhan symposium, the group flew to Guiyang and started the final segment of the workshop to examine Ediacaran and Cryogenian successions deposited in slope and basinal facies in eastern Guizhou, western Hunan, and northern Guangxi provinces. The Ediacaran successions in slope and basinal facies are dominated by fine-grained

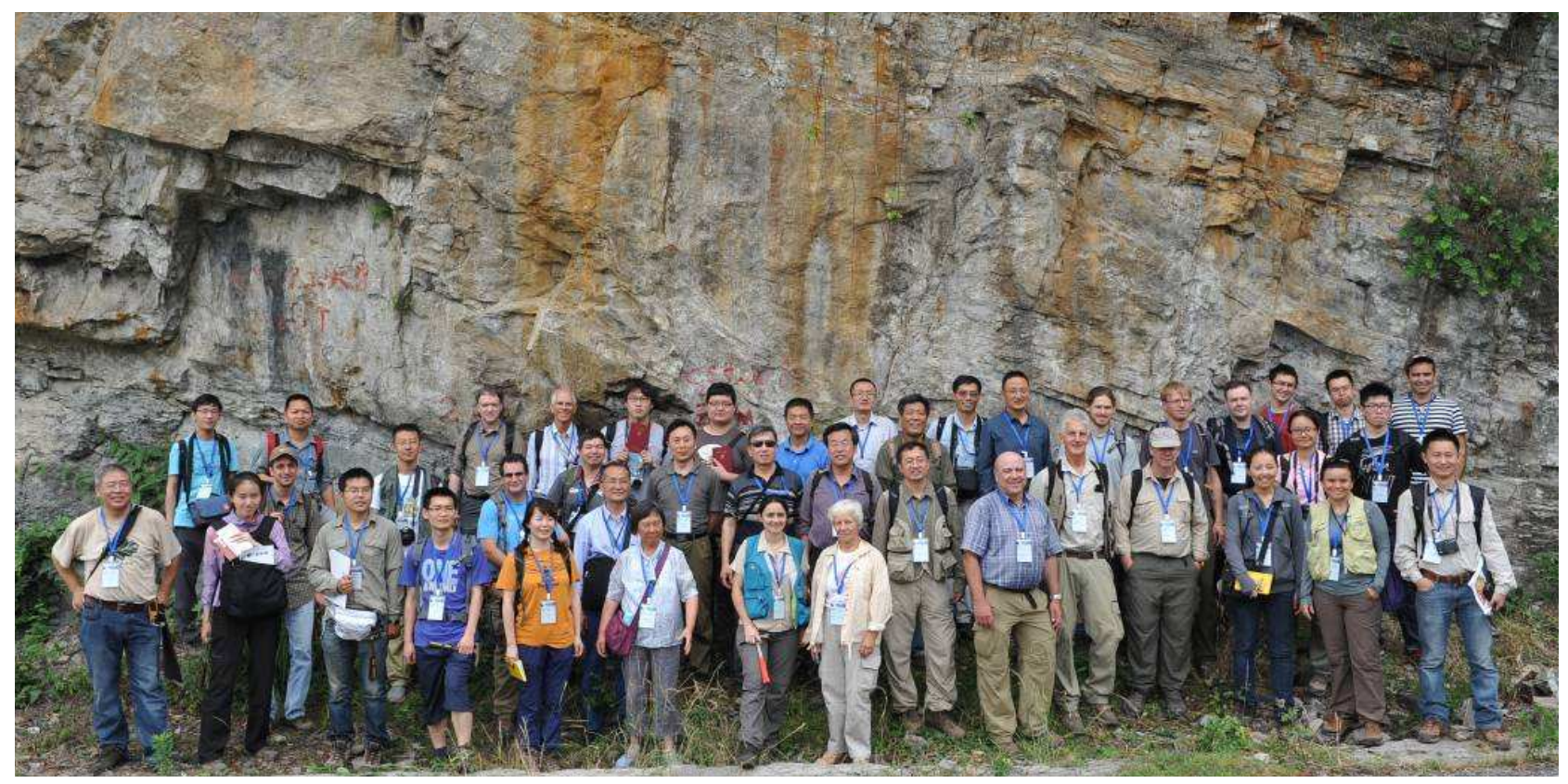

Figure 2. Group picture of participants in the first segment of the field workshop, in front of the Doushantuo cap carbonate at the Jiulongwan section in the Yangtze Gorges area. From left to right: Maoyan Zhu, Chengguo Guan, Qing Ouyang, Jan-Peter Duda, Ke Pang, Xiang Chen, Huan Cui, Lei Chen, Graham Shields-Zhou, Alan J. Kaufman, Ying Zhou, Carlos Alvarenga, Daizhao Chen, Qirui Zhang, Wei Wei, Weilin Deng, Pengju Liu, Wei Guangyi, Chongyu Yin, Milene Figueiredo, Xunlai Yuan, Jinnan Tong, Edi Mendes Guimarães, Xinqiang Wang, Shuhai Xiao, Linzhi Gao, Ganqing Jiang, Guy Narbonne, Chuanming Zhou, James Gehling, Peter Adamson, Douglas Erwin, Dmitry Grazhdankin, Konstantin Nagovitsin, Uyanga Bold, Alex Liu, Frances Liu, Lucieth Vieira, Zhou Wang, Zerui Liu, Dermeval Do Carmo, Zhenbing She. Not present: Soo-Yeun Ahn, Zhe Chen, Inara Gehling, Lanyun Miao, Dan Wang, Jinlong Wang. Photograph by Zhe Chen. 
siliciclastic sediments, including black shales and silicified mudstones. The Cryogenian System here is more complete than in the Yangtze Gorges area, including at least two discrete glacial diamictites. In addition to the Nantuo Formation diamictite, another glacial diamictite in the Chang' an Formation diamictite also occurs in slope and basinal facies. Likely an equivalent to the Sturtian glaciation in Australia or the Rapitan glaciation in North America, the Chang' an Formation diamictite is overlain by iron stone and sandstone of the Fulu Formation, black shale and rhodochrosite of the Datangpo Formation, and then the diamictite of the Nantuo Formation, which in places can reach over $1000 \mathrm{~m}$ in thickness. Although outcrops are spotty, this segment of the field workshop gave the participants an opportunity to appreciate the facies variation of Ediacaran and Ediacaran successions in South China and to debate on the source of silica in the silicified mudstone of the Ediacaran successions. Relevant to the Cryogenian Subcommission, the field excursion included a stop to examine the continuous transition from siltstone of the Gongdong Formation (possibly pre-Cryogenian) to dropstonebearing siltstone of the Cryogenian Chang' an Formation. At the end of the field excursion, voting and corresponding members of the Cryogenian Subcommission held a meeting to discuss the criteria for the definition of the Cryogenian System and plans for future work.

Together, the three segments of the field workshop gave the participants an overview of Ediacaran/Cryogenian stratigraphy of South China and opportunities to discuss various topics related to the subdivision and correlation of the Ediacaran and Cryogenian systems. There were a total of 64 geologists who participated in all or part of the three segments (Fig. 2). The field workshop was sponsored by International Commission on Stratigraphy, State Key Laboratory of Palaeobiology and Stratigraphy and Key Laboratory of Economic Stratigraphy and Palaeogeography (Nanjing Institute of Geology and Palaeontology, Chinese Academy of Sciences), Institute of Geology (Chinese Academy of Geological Sciences), China University of Geosciences (Wuhan), National Natural Science Foundation of China, U.S. National Science Foundation, Subcommission on Ediacaran Stratigraphy, Subcommission on Cryogenian Stratigraphy, All-China Stratigraphic Commission, IGCP 587, and Virginia Tech Department of Geosciences. The organization committee consisted of Shuhai Xiao (chair), Linzhi Gao, Ganqing Jiang, Pengju Liu, Dan Wang Shucheng Xie, Chongyu Yin, Xunlai Yuan, Chuanming Zhou, and Maoyan Zhu.

\section{Shuhai Xiao}

Department of Geosciences

Virginia Polytechnic and State

University, Blacksburg, VA 24061, USA

\section{Chuanming Zhou, Maoyan Zhu}

Nanjing Institute of Geology and

Palaeontology

Chinese Academy of Sciences

Nanjing 210008, China

\section{References}

Bottjer, D.J., and Clapham, M.E., 2006, Evolutionary paleoecology of Ediacaran benthic marine animals, in Xiao, S., and Kaufman, A. J., eds., Neoproterozoic Geobiology and Paleobiology: Dordrecht, The Netherlands, Springer, p. 91-114.

Bristow, T.F., Bonifacie, M., Derkowski, A., Eiler, J.M., and Grotzinger, J.P., 2011, A hydrothermal origin for isotopically anomalous cap dolostone cements from south China: Nature, v. 474 , p. 68-71.

Carbone, C., and Narbonne, G.M., 2014, When life got smart: the evolution of behavioral complexity through the Ediacaran and early Cambrian of NW Canada: Journal of Paleontology, v. 88, p. 309-330.

Chen, Z., Zhou, C., Meyer, M., Xiang, K., Schiffbauer, J.D., Yuan, X., and Xiao, S., 2013, Trace fossil evidence for Ediacaran bilaterian animals with complex behaviors: Precambrian Research, v. 224, p. 690- 701.

Chen, Z., Zhou, C., Xiao, S., Wang, W., Guan, C., Hua, H., and Yuan, X., 2014, New Ediacara fossils preserved in marine limestone and their ecological implications: Scientific Reports, v. 4, p. 4180; DOI:4110.1038/srep04180.

Condon, D., Zhu, M., Bowring, S., Wang, W., Yang, A., and Jin, Y., 2005, U-Pb ages from the Neoproterozoic Doushantuo Formation, China: Science, v. 308, p. 95-98.

Erwin, D.H., Laflamme, M., Tweedt, S.M., Sperling, E.A., Pisani, D., and Peterson, K.J., 2011, The Cambrian conundrum: Early divergence and later ecological success in the early history of animals: Science, v. 334, p. 1091-1097.

Fedonkin, M.A., Gehling, J.G., Grey, K., Narbonne, G.M., and Vickers-Rich, P., 2007, The Rise of Animals: Evolution and Diversification of the Kingdom Animalia, Baltimore, Johns Hopkins University Press, $326 \mathrm{p}$.

Gao, L., Lu, J., Ding, X., Wang, H., Liu, Y., and $\mathrm{Li}$, J., 2013, Zircon U-Pb dating of Neoproterozoic tuff in northern Gangxi and its implications for stratigraphic correlation: Geology in China, v. 40, p. 1443-1452.
Gehling, J.G., 1991, The case for Ediacaran fossil roots to the metazoan tree: Geological Society of India Memoir, v. 20, p. 181-224.

Gehling, J.G., and Droser, M.L., 2013, How well do fossil assemblages of the Ediacara Biota tell time?: Geology, v. 41, p. 447-450.

Grazhdankin, D., 2014, Patterns of evolution of the Ediacaran soft-bodied biota: Journal of Paleontology, v. 88, p. 269-283.

Grey, K., 2005, Ediacaran palynology of Australia: Memoirs of the Association of Australasian Palaeontologists, v. 31, p. 1-439.

Hoffman, P.F., 1991, Did the breakout of Laurentia turn Gondwanaland inside-out?: Science, v. 252, no. 5011, p. 1409-1412.

Hoffman, P.F., Kaufman, A.J., Halverson, G.P., and Schrag, D.P., 1998, A Neoproterozoic snowball Earth: Science, v. 281, p. 1342-1346.

Hoffman, P.F., and Schrag, D.P., 2002, The snowball Earth hypothesis: Testing the limits of global change: Terra Nova, v. 14, p. 129-155.

Jensen, S., Droser, M.L., and Gehling, J.G., 2006, A critical look at the Ediacaran trace fossil record, in Xiao, S., and Kaufman, A. J., eds., Neoproterozoic Geobiology and Paleobiology: Dordrecht, The Netherlands, Springer, p. 115157.

Jiang, G., Kennedy, M., Christie-Blick, N., Wu, H., and Zhang, S., 2006, Stratigraphy, sedimentary structures, and textures of the late Neoproterozoic Doushantuo cap carbonate in South China: Journal of Sedimentary Research, v. 76, p. 978-995.

Jiang, G., Kennedy, M.J., and Christie-Blick, N., 2003, Stable isotopic evidence for methane seeps in Neoproterozoic postglacial cap carbonates: Nature, v. 426, p. 822-826.

Kaufman, A.J., and Knoll, A.H., 1995, Neoproterozoic variations in the C-isotope composition of sea water: Stratigraphic and biogeochemical implications: Precambrian Research, v. 73, no. 3-4, p. 27-49.

Kirschvink, J.L., 1992, Late Proterozoic lowlatitude global glaciation: the snowball Earth, in Schopf, J. W., and Klein, C., eds., The Proterozoic Biosphere: A Multidisciplinary Study: Cambridge, Cambridge University Press, p. 51-52.

Knoll, A.H., Walter, M.R., Narbonne, G.M., and Christie-Blick, N., 2004, A new period for the geologic time scale: Science, v. 305, p. 621622.

Knoll, A.H., Walter, M.R., Narbonne, G.M., and Christie-Blick, N., 2006, The Ediacaran Period: a new addition to the geologic time scale: Lethaia, v. 39, p. 13-30.

Lenton, T.M., Boyle, R.A., Poulton, S.W., ShieldsZhou, G.A., and Butterfield, N.J., 2014, Coevolution of eukaryotes and ocean oxygenation in the Neoproterozoic era: Nature Geoscience, v. 7, p. 257-265.

Liu, A.G., McIlroy, D., and Brasier, M.D., 2010, First evidence for locomotion in the Ediacara biota from the 565 Ma Mistaken Point Formation, Newfoundland: Geology, v. 38, p. 123-126. 
Liu, A.G., McIlroy, D., Matthews, J.J., and Brasier, M.D., 2012, A new assemblage of juvenile Ediacaran fronds from the Drook Formation, Newfoundland: Journal of the Geological Society, London, v. 169, p. 395-403.

Liu, P., Xiao, S., Yin, C., Chen, S., Zhou, C., and Li, M., 2014, Ediacaran acanthomorphic acritarchs and other microfossils from chert nodules of the upper Doushantuo Formation in the Yangtze Gorges area, South China: Journal of Paleontology, v. 72 (supplement to No 1), p. 1-139.

Liu, P., Yin, C., Chen, S., Tang, F., and Gao, L., 2013, The biostratigraphic succession of acanthomorphic acritarchs of the Ediacaran Doushantuo Formation in the Yangtze Gorges area, South China and its biostratigraphic correlation with Australia: Precambrian Research, v. 225, p. 29-43.

Lyons, T.W., Reinhard, C.T., and Planavsky, N.J., 2014, The rise of oxygen in Earth's early ocean and atmosphere: Nature, v. 506, p. 307-315.

McFadden, K.A., Huang, J., Chu, X., Jiang, G., Kaufman, A.J., Zhou, C., Yuan, X., and Xiao, S., 2008, Pulsed oxygenation and biological evolution in the Ediacaran Doushantuo Formation: Proceedings of the National Academy of Sciences, USA, v. 105, p. 3197-3202.

McFadden, K.A., Xiao, S., Zhou, C., and Kowalewski, M., 2009, Quantitative evaluation of the biostratigraphic distribution of acanthomorphic acritarchs in the Ediacaran Doushantuo Formation in the Yangtze Gorges area, South China: Precambrian Research, v. 173, p. 170-190.

Meyer, M., Xiao, S., Gill, B.C., Schiffbauer, J.D., Chen, Z., Zhou, C., and Yuan, X., 2014, Interactions between Ediacaran animals and microbial mats: insights from Lamonte trevallis, a new trace fossil from the Dengying Formation of South China: Palaeogeography Palaeoclimatology Palaeoecology, v. 396, p. 62-74.

Narbonne, G.M., 2005, The Ediacara Biota: Neoproterozoic origin of animals and their ecosystems: Annual Review of Earth and Planetary Sciences, v. 33, p. 421-442.
Narbonne, G.M., Laflamme, M., Trusler, P.W., Dalrymple, R.W., and Greentree, C., 2014, Deep-water Ediacaran fossils from northwestern Canada: taphonomy, ecology, and evolution: Journal of Paleontology, v. 88, p. $207-223$.

Xiao, S., and Laflamme, M., 2009, On the eve of animal radiation: Phylogeny, ecology and evolution of the Ediacara biota: Trends in Ecology \& Evolution, v. 24, p. 31-40.

Xiao, S., McFadden, K.A., Peek, S., Kaufman, A.J., Zhou, C., Jiang, G., and Hu, J., 2012, Integrated chemostratigraphy of the Doushantuo Formation at the northern Xiaofenghe section (Yangtze Gorges, South China) and its implication for Ediacaran stratigraphic correlation and ocean redox models: Precambrian Research, v. 192-195, p. $125-141$.

Xiao, S., Yuan, X., Steiner, M., and Knoll, A.H., 2002, Macroscopic carbonaceous compressions in a terminal Proterozoic shale: A systematic reassessment of the Miaohe biota, South China: Journal of Paleontology, v. 76, p. 347-376.

Xiao, S., Zhang, Y., and Knoll, A.H., 1998, Threedimensional preservation of algae and animal embryos in a Neoproterozoic phosphorite: Nature, v. 391, p. 553-558.

Xiao, S., Zhou, C., Liu, P., Wang, D., and Yuan, X., 2014, Phosphatized acanthomorphic acritarchs and related microfossils from the Ediacaran Doushantuo Formation at Weng' an (South China) and their implications for biostratigraphic correlation: Journal of Paleontology, v. 88, p. 1-67.

Yin, C., Liu, P., Chen, S., Tang, F., Gao, L., and Wang, Z., 2009, Acritarch biostratigraphic succession of the Ediacaran Doushantuo Formation in the Yangtze Gorges: Acta Palaeontologica Sinica, v. 48, p. 146-154.

Yuan, X., Chen, Z., Xiao, S., Zhou, C., and Hua, H., 2011, An early Ediacaran assemblage of macroscopic and morphologically differentiated eukaryotes: Nature, v. 470, p. 390-393.

Zhang, Q.-R., Chu, X.-L., and Feng, L.-J., 2011,
Neoproterozoic glacial records in the Yangtze Region, China, in Arnaud, E., Halverson, G. P., and Shields-Zhou, G., eds., The Geological Record of Neoproterozoic Glaciations (Geological Society Memoirs, 36): London, Geological Society, p. 357-366.

Zhang, Q.-R., Li, X.-H., Feng, L.-J., Huang, J., and Song, B., 2008a, A new age constraint on the onset of the Neoproterozoic glaciations in the Yangtze Platform, South China: Journal of Geology, v. 116, p. 423-429.

Zhang, S., Jiang, G., and Han, Y., 2008b, The age of the Nantuo Formation and Nantuo glaciation in South China: Terra Nova, v. 20, p. 289-294.

Zhang, Y., Yin, L., Xiao, S., and Knoll, A.H., 1998, Permineralized fossils from the terminal Proterozoic Doushantuo Formation, South China: Journal of Paleontology, v. 72 (supplement to No. 4), p. 1-52.

Zhou, C., Bao, H., Peng, Y., and Yuan, X., 2010, Timing the deposition of ${ }^{17} \mathrm{O}$-depleted barite at the aftermath of Nantuo glacial meltdown in South China: Geology, v. 38, p. 903-906.

Zhou, C., Tucker, R., Xiao, S., Peng, Z., Yuan, X., and Chen, Z., 2004, New constraints on the ages of Neoproterozoic glaciations in South China: Geology, v. 32, p. 437-440.

Zhou, C., and Xiao, S., 2007, Ediacaran $\mathrm{d}^{13} \mathrm{C}$ chemostratigraphy of South China: Chemical Geology, v. 237, p. 89-108.

Zhou, C., Xie, G., McFadden, K., Xiao, S., and Yuan, X., 2007, The diversification and extinction of Doushantuo-Pertatataka acritarchs in South China: Causes and biostratigraphic significance: Geological Journal, v. 42, p. 229-262.

Zhu, M., Lu, M., Zhang, J., Zhao, F., Li, G., Yang, A., Zhao, X., and Zhao, M., 2013, Carbon isotope chemostratigraphy and sedimentary facies evolution of the Ediacaran Doushantuo Formation in western Hubei, South China: Precambrian Research, v. 225, p. 7- 28.

Zhu, M., Zhang, J., and Yang, A., 2007, Integrated Ediacaran (Sinian) chronostratigraphy of South China: Palaeogeography Palaeoclimatology Palaeoecology, v. 254, p. 7-61. 